\title{
Bioremediation of Anthracene, Phenanthrene and Phenol by Cunninghamella echinulata
}

\author{
E.M. El-Morsy ${ }^{\mathrm{a}}$, E.E. Hafez ${ }^{\mathrm{b}}$, M.T. Mohesien ${ }^{\mathrm{a}}$, G.M. Abogadallah ${ }^{\mathrm{a}}$ \\ ${ }^{a}$ Department of Botany, Faculty of Science, Damietta University, Egypt \\ ${ }^{\mathrm{b}}$ Department of Plant Molecular Pathology, Arid Lands Cultivation Research Institute (ALCRI) City for \\ Scientific Researches and Technology Application, New Borg EL-Arab, Alexandria, Egypt
}

*Corresponding author (email: mohesienmarwa@yahoo.com)

\begin{abstract}
Oil-polluted areas contain large amounts of poly-aromatic hydrocarbons (PAHs) which represent severe hazards on the ambient environment. Fungal strains were isolated from different contaminated sites in the Mediterranean coast and middle Delta, Egypt and screened for PAHs degradation. Hydrocarbon-enriched media was used to isolate the anthracene-, phenanthrene- and phenol-degrading fungi. Thirteen fungal isolates showed high degradation activities for anthracene, phenanthrene and phenol. One isolate was selected possessing high degradation ability and incubation period and was identified based on $18 \mathrm{~S}$ rDNA sequence. Partial sequence of $18 \mathrm{~S}$ rDNA revealed that this isolate is identified as Cunninghamella echinulata. Laccase enzyme produced by this fungus was subsequently evaluated for its degradative ability towards PAHs mixtures. The percentage of degradation varied from $96.035 \%$ to $99.986 \%$ of the tested PAHs. After an incubation period of 45 days, 5\% of PAHs gave the highest degradation activity among all concentrations used. The kinetics of PAHs degradation is presented along with the feasibility of using Cunninghamella echinulata for bioremediation
\end{abstract}

Keywords: 18S rDNA genes, biodegradation, environmental pollution, laccase, polycyclic aromatic hydrocarbons

\section{Introduction}

Environmental pollution is continuously increasing with the industrial development. Pollution causes many hazards for all organismsincluding humans- such as carcinogenicity and toxicity. There has been increasing pollution with hydrocarbon compounds, many of which are considered to be potential health hazard [1]. Some hydrocarbon pollutants are polycyclic aromatic hydrocarbons (PAHs). Four classes of hydrocarbons are present: straight chain alkanes, branched chain alkanes, cycloalkanes and polyaromatic hydrocarbon [2]. PAHs are among the most harmful substances for human, marine and fresh water, soil fauna and flora. PAHs are a large group of organic compounds with two or more fused aromatic rings in linear, angular, or cluster arrangements. They have relatively low solubility in water, but are highly lipophilic [1].

Although PAHs can exist in over 100 different combinations, the most common are treated as a group of 15; they are: acenaphthene, acenaphtylene, anthracene, pyrene, 
benzo(b)fluoranthene, benzo(k)fluoranthene,

benzo(ghi)perylene, chrysene, dibenz(a,h)anthracene, Fluoranthene, Fluorine, indeno(1,2,3cd)pyrene, phenanthrene, pyrene [3].

Anthracene and phenanthrene are tri-cyclic aromatic hydrocarbons that are found at high concentrations in polycyclic aromatic hydrocarbon (PAH)-contaminated sediments, surface soils and waste sites. These hydrophobic contaminants are widely distributed in the environment, occurring as natural constituents of fossil fuels and their anthropogenic pyrolysis products [1]. Unlike the higher-molecular-weight PAHs, phenanthrene and anthracene do not pose a risk to human health, since they exhibit no genotoxic or carcinogenic effects. However, they have been shown to be toxic to fish and algae [4]. Phenol and phenolic compounds are well known components in a wide variety of waste waters including these from coal conversion processes, coking plants, petroleum refineries and several chemical industries, as pharmaceuticals, resin and dye manufactures [5].

PAHs have been reported to be degraded by some microorganisms in the soil [1]. The ability of fungi to transform a wide variety of hazardous chemicals is interesting as bioremediation strategy [6]. A large number of diverse microorganisms including bacteria, micro-algae, fungi, protozoa and actinomycetes are indigenous in most soils. Some microorganisms are capable of biodegrading petroleum hydrocarbons $[7,8]$. Petroleum hydrocarbon utilizing microorganisms have recently been isolated in large numbers form a wide variety of natural aquatic and terrestrial environments.

There are two essential characteristics that define hydrocarbon-oxidizing bacteria: 1) hydrocarbon-group-specific oxygenases and 2) mechanisms for optimizing contact between the bacterium and the hydrocarbon [9]. Some filamentous fungi possess some attributes that give them a good potential of degradation, since those microorganisms can ramify quickly on the substratum and through the secretion of extracellular enzymes. Moreover, the fungi are able to grow under an array of environmental conditions of stress, for example: environment with low $\mathrm{pH}$ values or poor in nutrients and with low water activity. Several authors have made lists containing bacterial and fungal genera that are able to degrade a wide spectrum of pollutants, proceeding from marine atmosphere as well as the soil. In accordance with several scientific publications, it can be pointed out that, amongst the filamentous fungi Trichoderma and Mortierella spp. are the most common ones isolated from the soil. Aspergillus and Penicillium spp. have frequently been isolated from marine and terrestrial environments.

The ability of fungi to transform a wide variety of hazardous chemicals has attracted interest in using them in bioremediation [10]. The white rot fungi are unique among eukaryotes for having evolved nonspecific methods for the degradation of lignin; curiously they do not use lignin as a carbon source for their growth [11]. Lignin degradation is, therefore, essentially a secondary metabolic process, not required for the main growth process. Lamar et al. [12] compared the abilities of three lignin-degrading fungi, Phanerochaete chrysosporium, P. sordida and Tramates hirsuta to degrade Pentachlorophenyl (PCP) and creosote in soil. Inoculation of soil with $10 \% \quad(\mathrm{wt} / \mathrm{wt})$ Phanerochaete sordida resulted in the greatest decrease of PCP and creosote. P. sordida was also most useful in the degradation of PAHs from soil. Davis et al. [13] showed that $P$. sordida was capable of degrading efficiently the three ring PAHs, but less efficiently the four-ring PAHs.

Laccase (Lac), manganese peroxidase ( $\mathrm{MnP}$ ) and lignin peroxidase $(\mathrm{LiP})$ are the major lignin degradation enzymes of white-rot fungus [14]. Laccase is a multicopper oxidase which can degrade a variety of complex structures of xenobiotics.

The aim of this study was to isolate fungi with degradation activity of PHAs and to investigate the role of laccase in the degradation process.

\section{Materials and methods}

\section{Study area}

The study area is a part of Mediterranean coast and Delta of Egypt. It extends for about $500 \mathrm{~km}$ between Port Said to Alexandria and $500 \mathrm{Km}$ to Delta (Port Said, 1; New Damietta, 2; Gamasa, 3; Balteem, 4; Kafr Zaiat, 5; and Alexandria, 6-8). From each location (1-5), composite samples were collected from two different sites, (a) and (b). Sample regions (a) and (b) are located on the tidal region and is about $2 \mathrm{~km}$ far from each other (horizontally), whereas (c) and (d) samples are sub-tidal and collected about $50 \mathrm{~m} 2$ away from a and $\mathrm{b}$ on land side. In Alexandria three localities were sampled viz; Abu Quir beach (6), AlMontazah beach (7) and Al-Mandara beach (8). 
Sample region (a) is on tidal site and c is far from it by $50 \mathrm{~m} 2$ landside.

\section{Collection of soil samples}

Composite soil samples were collected from 26 sites representing 8 selected localities along the Mediterranean Sea coast of Egypt and were separately transferred into clean plastic bags. Each sample was divided into two portions. The first portion was used directly for microbiological assay and then stored in cold conditions. The second portion was stored for physical and chemical analysis.

\section{Soil characteristics}

In 1:5 soil extracts (100 grams soil were used) the $\mathrm{pH}$ and the total soluble salts (TDS) were determined by using Corning $\mathrm{pH}$-meter 215 and Sporule model 10 meter. The organic matter content (OC) was determined as recommended by Jackson [15]. Moisture content (MO) was evaluated as difference in weight between oven dry soil $\left(105^{\circ} \mathrm{C}\right)$ and fresh soil. Water retention capacity (WRC) was assessed as in Piper [16]. Total pore space (porosity) is equal to the difference between the volume of soil in dry and wet conditions. Soil texture was determined by separation of different soil fractions by sieving method. The amount of each fraction was expressed as percentage of original weight used.

For determination of soil nutrients, dried soil material was ground into fine powder prior to digestion by sulphuric acid peroxide method of digestion [17] in a Kjeldal digestion flask. Total nitrogen (TN) was quantitatively determined by Markham micro-Kjeldal apparatus [18]. Ammonia-N (Nessler method) in the distillate was estimated colorimetrically at $450 \mathrm{~nm}$ by using Spectronic $20 \mathrm{D}$ spectrophotometer [19]. Total petroleum hydrocarbons (TPH) were measured in ten grams of soil. The soil was dehydrated with $\mathrm{Na}_{2} \mathrm{SO}_{4}$ and mixed for $30 \mathrm{~min}$ with $10 \mathrm{ml}$ of 1,1,2-trichlorotrifluoroethane; the TPH content of the filtrate was quantified as described in standard method [20]. Total phosphorus (\%) was determined spectrophotometrically at $710 \mathrm{~nm}$ by modified method of John [21]. $\mathrm{Na}^{+}, \mathrm{K}^{+}$and $\mathrm{Ca}^{+2}$ were determined in the previously prepared digest using a Flame Photometer type M7D.

\section{Microbial enrichment and screening of isolated fungi}

Adaptation and enrichment procedure involved an initial addition of $0.1 \mathrm{~g}$ contaminated soil with PAHs from Mediterranean coast and Delta of Egypt with different concentrations of studied PAHs $\left(100,200,300,400,500 \mathrm{mg} 100 \mathrm{ml}^{-1}\right)$ into the mineral Czapekdox broth medium as a sole carbon source (the PAHs was prepared with equal weights of anthracene, phenanthrene and phenol). Then the medium was maintained at $30 \pm 2^{\circ} \mathrm{C}$ under shaking at $200 \mathrm{rpm}$. After 4 days, one $\mathrm{ml}$ of each sample was added and plated on Czapekdox agar medium. Then the plates were incubated for 7 days at $30 \pm 2^{\circ} \mathrm{C}$ in the dark.

Fungal colonies were purified, and then screened on Czapekdox agar medium with the same previous concentrations of PAHs, and then growth was observed after 7 days and the diameter of growth was recorded.

A strain with high degradation activity was selected from the isolated fungi, and then was preserved on slants of the following medium: malt extract $3.0 \mathrm{~g} \mathrm{l}^{-1}$, yeast extract $3.0 \mathrm{~g} \mathrm{l}^{-1}$, peptone $5.0 \mathrm{~g} \mathrm{l}^{-1}$, glucose $10 \mathrm{~g} \mathrm{l}^{-1}$ and agar $20 \mathrm{~g} \mathrm{l}^{-}$ ${ }^{1}$, and stored at $4 \pm 1^{\circ} \mathrm{C}$ for further use.

\section{Microorganism identification}

The selected organism was identified using morphological methods by using various agar media for identification according to Arx Von [22], Barron [23], Domsch et al., [24], Ellis [25,26], Kozakiewicz [27], Raper and Fennel [28], Raper and Thom [29] and Rifai [30], in addition to different molecular techniques at Molecular Plant Pathology Department, Arid Lands Cultivation Research Institute (ALCRI), City for Scientific Researches and Technology Application, New Borg EL-Arab, Alexandria, Egypt.

\section{Fingerprinting of the selected organism DNA extraction}

The genomic DNA was extracted using Wizard DNA Purification Kit (Promega, USA) following the protocol of genomic isolation fungi.

PCR amplification and sequencing of ITS- $18 S$ rRNA region

The oligonucleotide primers used for amplification and sequencing of the ITS regions 
including 18S rRNA were those described by White et al. [31]. The primers sequences ITS1 (5'-TCCGTAGGTGAACCTGCGG-3') and ITS4 (5'-TCCTCCGCTTATTGATATGC-3') were made by Bioneer (USA). Amplification reactions were performed in $25 \mu \mathrm{l}$ containing $2.5 \mu \mathrm{l}$ of each primer (20 picomole), $2.5 \mu \mathrm{l}$ of genomic DNA $\left(5 \mu \mathrm{g} \mathrm{ml}^{-1}\right)$ and one PCR bead (PuReTaq Ready-To-Go; Amersham Biosciences). PCR was performed using the initial denaturation at 94 ${ }^{\circ} \mathrm{C}$ for $4 \mathrm{~min}$, followed by 35 cycles at $94{ }^{\circ} \mathrm{C}$ for 1 min, $55^{\circ} \mathrm{C}$ for $1 \mathrm{~min}$ and $72^{\circ} \mathrm{C}$ for $2 \mathrm{~min}$, then final extension at $72{ }^{\circ} \mathrm{C}$ for $10 \mathrm{~min}$.

\section{DNA sequencing and accession number}

DNA sequence for the ITS gene was performed by Macrogene Company (Korea). The sequences were submitted to NCBI GenBank database and DNA sequences were aligned in sequin program (http://www.ncbi.nlm.nih.gov/sequin).

\section{Alignment and phylogenetic analyses}

BLAST [32] was performed for the obtained ITS DNA sequence to match the best similarities with other related ITSs on database. The best DNA sequence similarities with our ITS region were obtained from NCBI GenBank and aligned using CLUSTAL W [33]. Unalignable regions were excluded and the sequences from the same species and unidentified organisms were discarded. Finally, Phylogenetic tree analyses were conducted using $M E G A$ version 4 [34].

\section{Degradation test}

The biodegradation was studied in the mineral medium containing $(1 \%, 2 \%, 3 \%, 4 \%$ and $5 \%$ of PAHs mixture (100, 200, 300, 400, $500 \mathrm{mg} 100$ $\mathrm{ml}^{-1}$ ) into the mineral Czapekdox broth medium as a sole carbon source, the mixture was prepared in equal weights of anthracene, phenanthrene and phenol and inoculated with the selected fungi.

HPLC analyses of the extracted PAHS for the determination of degradation

This method was according to Anderson and Henrysson [35]. At two-week interval samples, consisting of the whole flasks were collected and toluene $(100 \mathrm{ml})$, was added to each flask, which were thoroughly mixed and placed in a water bath at $100^{\circ} \mathrm{C}$ for 3 hours. When the flasks had reached room temperature, $2 \mathrm{ml}$ of the toluene mixture was removed, filtered with a 0.22 membrane using a glass syringe and used for the HPLC analyses.

\section{Assay of laccase activity}

One unit (U) of laccase activity was defined as the amount of enzyme oxidizing 1 mol (2,2'Azinobis [3-ethylbenzothiazoline-6-sulfonic acid]-diammonium salt) ABTS $\mathrm{min}^{-1}$. The assay mixture contained $0.2 \mathrm{~mol} \mathrm{l}^{-1}$ acetic acid-sodium acetate buffer solution ( $\mathrm{pH} 5.0$ ), $5 \mathrm{mmol} \mathrm{l}^{-1}$ ABTS and a certain amount of enzyme solution. The oxidation of ABTS was followed by an absorbance increase of $0-3 \mathrm{~min}$ at $420 \mathrm{~nm}$ with spectrophotometer [36]

\section{Statistical analysis}

Data generated were analyzed using (SPSS v.18). Statistically significant differences (at 0.05 level) among means of experiment results were evaluated by analysis of variance and means compared by one-way-ANOVA test Graphs were made using Sigma Plot v.18 software.

\section{Results and Discussion}

All the results of the soil samples are shown in Table 1. The examined soils are sandy, with very low nutrient content and slightly alkaline with $\mathrm{pH}$ ranged from 7.09-8.79 and with moderate to high electric conductivity; EC (2 - 80 mmhose $\left.\mathrm{cm}^{-1}\right)$, organic carbon; OC $\left(0.06-1.7 \mathrm{mg} \mathrm{g}^{-1}\right.$ dry weight), total nitrogen; TN (0.004 - $0.20 \mathrm{mg} \mathrm{g}^{-1}$ dry weight), phosphorus; TP (0.001 - $0.012 \%)$, sodium ion $(23.09-57.8 \%)$, potassium ion (1.2 $3.61 \%)$ and calcium ion $(8-112.17 \%)$. The soil hydrocarbon content varied considerably between the different collected soils. All the samples were contaminated and the hydrocarbon content ranged from 0.025 to $0.422 \mathrm{mg} \mathrm{l}^{-1}$. It was also obvious that sub-tidal samples are less in its constituents of EC, OC and TP than tidal ones. Conversely, TH and TN contents were higher in sub-tidal region than tidal one (Table 1).

Prince [37] reported that petroleum hydrocarbons are an excellent source of carbon and energy for certain microbes that could utilize and degrade them. However, hydrocarbons are deficient foods in that they do not contain significant concentrations of other nutrients, such as nitrogen and phosphorus, which are essential for microbial growth. Diesel oil is mainly 
composed of simple unbranched n-alkanes and around $4 \%$ polyaromatic compounds [38]. Alkanes are normally toxic to microorganisms.

Thirteen fungal species were isolated from soil contaminated with hydrocarbon namely; Alternaria alternata, Syncephalastrum racemosum, Aspergillus flavus, A. terreus, A. niger, A. tubingens, Trichoderma asperellum, Fusarium proliferatum, F. oxysporum, Pleurotus ostreatus, Rhizopus oryzae, Penicillium chrysogenum and Cunninghamella echinulata (Table 2). These genera and their species have a worldwide distribution [30]. They are mostly isolated from oil-polluted soils [8,39] and reported to be active consumers of hydrocarbons and strongly lipolytic [40,41].

All species were very frequently $(14-83 \%)$ isolated except Syncephalastrum racemosum which was frequently (2\%) isolated. The variation between them occurred only in the total colony count not in occurrence. This indicated that the soil properties may affect the abundance of species and not its existence. Spearman correlation indicated a significant negative correlation between hydrocarbon content $(\mathrm{TH})$ and fungal count that is mean that the fungal abundance was affected by changes in TH level in soil. Alike, Reid et al. [42] stated that several factors including soil type and physico-chemical properties of the contaminant determine the fate and behaviour of PAHs in the soil.

Fungal isolation and screening on PAHs containing media was shown in Fig. 1-3. Fig. 1 illustrated that, the ability of isolated species to grow on phenol were variable. These were significantly increases as indicted by increasing the colony diameter. Consequently, Cunninghamella and Penicillium chrysogenum, were appear to be the best colonizers at $1 \%$ whereas their least growth was obtained at phenol concentration of $2 \%$.

Table 1 Edaphic properties of soil samples collected from different sites along the Mediterranean coast and delta of Egypt.

\begin{tabular}{|c|c|c|c|c|c|c|c|c|c|c|c|c|c|}
\hline \multicolumn{2}{|l|}{ Localities } & Sample & Soil type & $\begin{array}{l}\mathrm{MC} \\
(\%)\end{array}$ & $\begin{array}{l}\text { EC } \\
\text { mmbose } \\
\mathrm{cm}^{-1} \text { ) }\end{array}$ & $\begin{array}{c}\mathrm{OC} \\
\text { (mg g } \\
\text { dry weight) }\end{array}$ & $\begin{array}{c}\mathrm{TN} \\
\text { (mg g.l} \\
\text { dry weight) }\end{array}$ & $\underset{\left(\mathrm{mg} \mathrm{I}^{-1}\right)}{\mathrm{TH}}$ & $\mathrm{pH}$ & $\begin{array}{l}\text { TP } \\
(\%)\end{array}$ & $\begin{array}{l}\mathrm{Na}^{+} \\
(\%)\end{array}$ & $\begin{array}{l}\mathrm{K}^{+} \\
(\%)\end{array}$ & $\begin{array}{l}\mathrm{Ca}^{-2} \\
(\%)\end{array}$ \\
\hline \multirow{4}{*}{\multicolumn{2}{|c|}{$\overline{\text { Port said }}$}} & 1a & Sandy & 3.33 & 30 & 0.75 & 0.019 & 0.237 & 7.09 & 0.005 & 42.2 & 3.0 & 16 \\
\hline & & $1 \mathrm{c}$ & Sandy & 2.10 & 13 & 0.81 & 0.017 & 0.356 & 8.00 & 0.011 & 42.2 & 3.0 & 12 \\
\hline & & 16 & Sandy & 2.05 & 28 & 0.75 & 0.004 & 0.255 & 8.00 & 0.006 & 31.1 & 2.4 & 10 \\
\hline & & $1 d$ & Sandy & 1.05 & 18 & 0.60 & 0.025 & 0.381 & 7.80 & 0.003 & 28.9 & 1.8 & 8 \\
\hline \multirow{4}{*}{\multicolumn{2}{|c|}{ New Damietta }} & $2 a$ & Sandy & 4.20 & 13 & 1.10 & 0.200 & 0.294 & 8.79 & 0.011 & 24.2 & 2.9 & 22 \\
\hline & & $2 \mathrm{c}$ & Sandy & 4.30 & 14 & 1.20 & 0.030 & 0.422 & 8.08 & 0.001 & 24.8 & 1.4 & 33 \\
\hline & & $2 \mathrm{~b}$ & Sandy & 2.60 & 17 & 1.30 & 0.050 & 0.034 & 8.22 & 0.002 & 23.1 & 1.8 & 12 \\
\hline & & $2 d$ & Sandy & 2.80 & 10 & 1.70 & 0.010 & 0.366 & 7.90 & 0.001 & 30.2 & 1.9 & 17 \\
\hline \multirow{4}{*}{\multicolumn{2}{|c|}{ Gamasa }} & $3 a$ & Sandy & 3.37 & 30 & 0.99 & 0.019 & 0.334 & 8.19 & 0.002 & 42.2 & 3.0 & 22 \\
\hline & & $3 \mathrm{c}$ & Sandy & 0.01 & 13 & 0.06 & 0.017 & 0.237 & 8.14 & 0.005 & 42.2 & 3.0 & 16 \\
\hline & & $3 b$ & Sandy & 0.24 & 28 & 0.06 & 0.004 & 0.356 & 8.21 & 0.011 & 31.1 & 2.4 & 12 \\
\hline & & $3 \mathrm{~d}$ & Sandy & 0.10 & 18 & 1.20 & 0.025 & 0.255 & 7.90 & 0.006 & 28.9 & 1.8 & 10 \\
\hline \multirow{4}{*}{\multicolumn{2}{|c|}{ Kaft Zaiat }} & $4 a$ & Sandy & 0.65 & 26 & 0.24 & 0.039 & 0.381 & 7.90 & 0.003 & 57.8 & 2.4 & 8 \\
\hline & & $4 \mathrm{c}$ & Sandy & 0.52 & 80 & 1.05 & 0.037 & 0.391 & 7.90 & 0.005 & 37.8 & 1.2 & 8 \\
\hline & & $4 b$ & Sandy & 2.08 & 30 & 1.47 & 0.019 & 0.039 & 7.80 & 0.007 & 26.7 & 1.2 & 8 \\
\hline & & $4 d$ & Sandy & 1.30 & 21 & 1.11 & 0.009 & 0.025 & 8.00 & 0.012 & 28.9 & 1.2 & 36 \\
\hline \multirow{4}{*}{\multicolumn{2}{|c|}{ Balteem }} & $5 \mathrm{a}$ & Sandy & 4.20 & 42 & 1.14 & 0.098 & 0.393 & 8.38 & 0.002 & 28.9 & 3.6 & 30 \\
\hline & & $5 c$ & Sandy & 2.60 & 2.0 & 0.93 & 0.036 & 0.310 & 8.03 & 0.004 & 24.5 & 1.8 & 12 \\
\hline & & $5 b$ & Sandy & 3.44 & 38 & 1.65 & 0.009 & 0.262 & 7.90 & 0.005 & 33.4 & 2.4 & 10 \\
\hline & & $5 \mathrm{~d}$ & Sandy & 2.56 & 47 & 0.36 & 0.049 & 0.293 & 7.80 & 0.007 & 28.9 & 1.8 & 18 \\
\hline \multirow[t]{6}{*}{ Alexandria } & Abu Quir & 6a & Sandy & 7.21 & 35 & 0.54 & 0.023 & 0.310 & 8.09 & 0.003 & 42.2 & 3.6 & 32 \\
\hline & & $6 \mathrm{c}$ & Sandy & 5.33 & 29 & 0.96 & 0.015 & 0.273 & 8.03 & 0.002 & 33.6 & 2.4 & 64 \\
\hline & Al-Montazah & $7 \mathrm{a}$ & Sandy & 4.77 & 23 & 0.75 & 0.007 & 0.293 & 7.88 & 0.003 & 31.1 & 1.8 & 84 \\
\hline & & $7 \mathrm{c}$ & Sandy & 2.90 & 4.0 & 0.81 & 0.023 & 0.310 & 8.03 & 0.002 & 35.6 & 1.8 & 84 \\
\hline & A1-Mandara & $8 a$ & Sandy & 7.30 & 37 & 0.75 & 0.022 & 0.388 & 8.03 & 0.002 & 51.1 & 2.4 & 112 \\
\hline & & $8 \mathrm{c}$ & Sandy & 4.30 & 16 & 0.81 & 0.017 & 0.252 & 7.85 & 0.002 & 53.4 & 2.4 & 22 \\
\hline
\end{tabular}

$\mathrm{a}$ and $\mathrm{b}$ tidal samples; $\mathrm{c}$ and $\mathrm{d}$, sub-tidal. 
Table 2 Record of fungi isolated from sandy beaches along the Mediterranean coast and Delta of Egypt.

\begin{tabular}{|c|c|c|c|c|}
\hline & \multicolumn{2}{|c|}{ Tidal samples } & \multicolumn{2}{|c|}{ Sub-tidal samples } \\
\hline & Total count & $\%$ Occurrence & Total count & $\%$ Occurrence \\
\hline Alternaria alternata & 68 & 68 & 54 & 54 \\
\hline Aspergillus flavus & 156 & 83 & 181 & 79 \\
\hline A. niger & 32 & 43 & 51 & 52 \\
\hline A. terreus & 49 & 42 & 74 & 29 \\
\hline A. tubingens & 18 & 21 & 9 & 18 \\
\hline Cunninghamella echinulata & 43 & 68 & 56 & 64 \\
\hline Fusarium oxysporum & 36 & 50 & 56 & 36 \\
\hline$F$. proliferatum & 16 & 36 & 18 & 39 \\
\hline Penicillium chrysogenum & 41 & 61 & 71 & 68 \\
\hline Pleurotus ostreatus & 7 & 14 & 11 & 18 \\
\hline Rhizopus oryzae & 41 & 61 & 74 & 29 \\
\hline Syncephalastrum racemosum & 2 & 4 & 1 & 2 \\
\hline Trichoderma asperellum & 40 & 57 & 35 & 46 \\
\hline
\end{tabular}
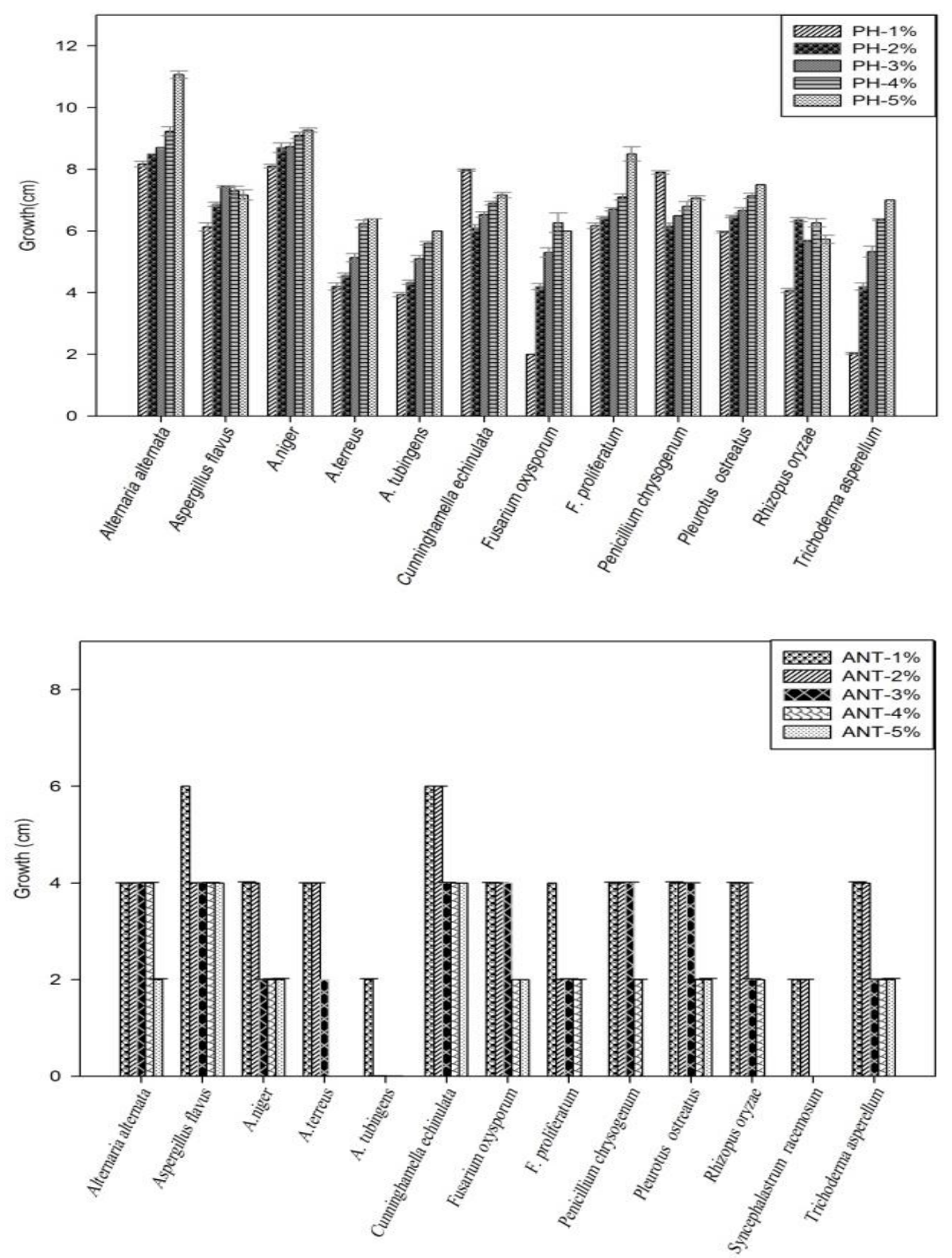

Fig. 1 The growth of the isolated fungi on the phenol (PH). Fungi were grown on Czapekdox medium containing $\mathrm{PH}$ as a sole carbon source for 7 days at $30^{\circ} \mathrm{C}$. Bars are means of colonies diameters (cm) \pm SE.

Fig. 2 The growth of the isolated fungi on Anthracene (Ant). Fungi were grown on Czapekdox medium containing Ant as a sole carbon source for 7 days at $30^{\circ} \mathrm{C}$. Bars are means of colonies diameters (cm) \pm SE. 
On the contrary, Rhizopus oryzae showed their highest growth at phenol concentration of $2 \%$ and its least growth was obtained at $1 \%$ concentration. Moreover, Pleurotus ostreatus, Fusarium oxysporum, $F$. proliferatum, Trichoderma asperellum, Aspergillus tubingens, A. niger, A. terreus, A. flavus and Alternaria alternata, showed the highest growth at phenol concentration of $5 \%$, whereas their reduced growth was obtained at phenol concentration of $1 \%$.

The results in Fig. 2 point out that, the ability of tested fungi to grow on anthracene were variable as recognized by increases in colony diameter. Therefore, Cunninghamella, Rhizopus oryzae, Penicillium chrysogenum, Pleurotus ostreatus, Fusarium oxysporum, F. proliferatum, Trichoderma asperellum, A. tubingens, A. niger, A. terreus, Aspergillus flavus and Alternaria alternate were the best colonizers at $1 \%$.

Fig. 3 illustrates that, the ability of fungi to grow on phenanthrene were also variable and significantly increases as recognized by increases in colony diameter. Cunninghamella, Penicillium chrysogenum, Pleurotus ostreatus, Fusarium oxysporum, $F$. proliferatum, Trichoderma asperellum, A. tubingens, A. niger, A. terreus, Aspergillus flavus and Alternaria alternate, were appear to be the best colonizers at $1 \%$ concentration of phenanthrene. While Rhizopus oryzae gave the same growth value with different concentrations of phenanthrene.

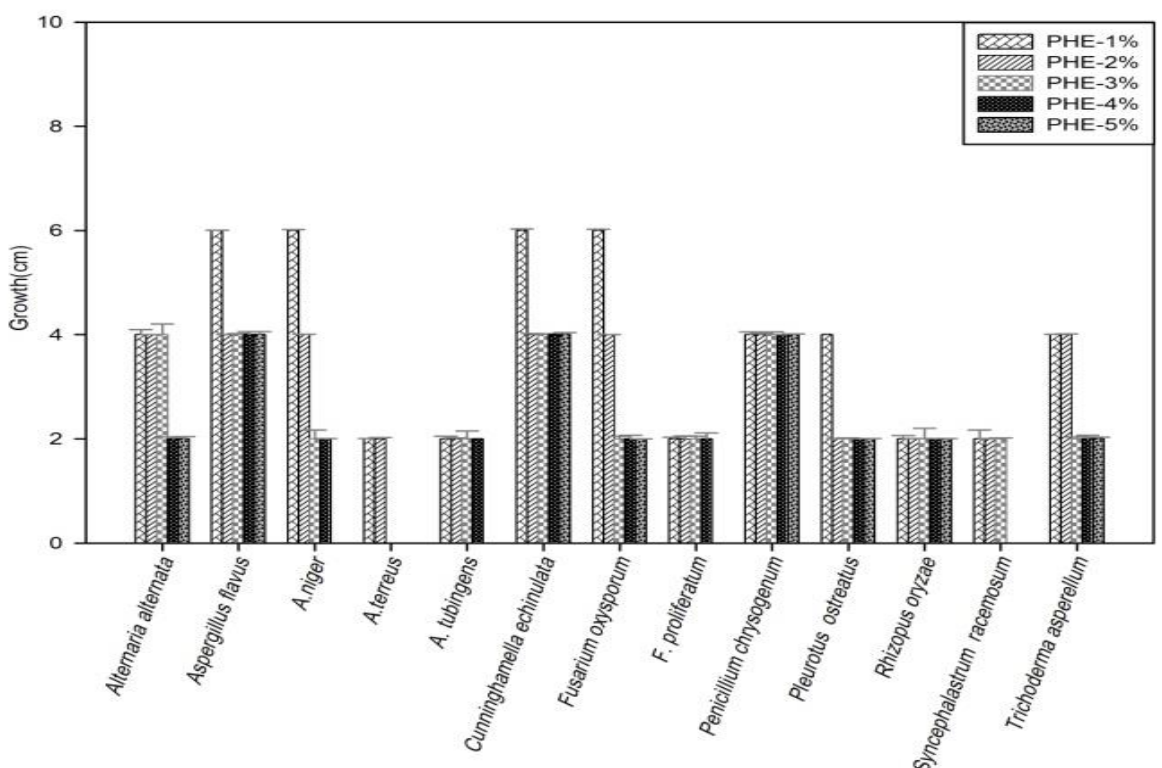

At the end of this part Cunninghamella echinulata was selected for further studies according to their high degradation activity towards PAHs. The fungus was identified as based on morphological characteristics. The DNA sequence of its rDNA is shown in Fig. 4. The obtained 475 base nucleotide sequence was compared with the corresponding $18 \mathrm{~s}$ ribosomal RNA gene in NCBI to obtain the Phylogenetic tree shown in the Fig. 5.

Cunninghamella echinulata was found to be able to degrade three-ring polyaromatic hydrocarbons (anthracene and phenanthrene) and phenol aromatic compounds. The percentage of degradation varied from $96.035 \%$ to $99.986 \%$ of the tested PAHs (Table 3). The fungus produces laccase enzyme that is able to degrade PAHs compounds. For biodegradation of phenanthrene tested at levels of 1, 2, 3, 4 and $5 \%$ the fungus was able to degrade them to levels of 99.9, 99.4, 99.98, 99.7 and $99.7 \%$ respectively. Alike, $C u$. echinulata was able to degrade 99.98375, 99.4712, 99.97874, 99.7685 and $99.8435 \%$ for the anthracene concentrations of 1,2,3,4 and $5 \%$, respectively. Phenol was tested at the same levels $(1,2,3,4$ and 5\%) that also degraded to $96.035,99.4858,99.7578,99.8184$ and 99.1286 $\%$ respectively. The percentage of degradation varied from $96.035 \%$ to $99.986 \%$ of the tested PAHs (Table 2). Moreover, the experiments conducted with PAHs (mixture) as a sole carbon source indicated that the organism was capable of utilizing this material as a source of carbon for its growth.

Enzyme activities are measures of microbial activity in soil [43] and are indicative of the onset of hydrocarbon biodegradation [44]. The data revealed that Cunninghamella echinulata has the 
properties of an efficient phenol, phenanthrene and anthracene degrading microorganism. The efficiency of a certain catabolic pathway often depends on the properties of the involved key enzyme(s). Laccase activity was measured frequently as indicators of the microbial activity during the bioremediation processes in this investigation. The biological activity increased during the phase of the highest degradation activity.

Table 3 The percentage of the degradation of Cunninghamella grown in $1 \%-5 \%$ of mixing polyhydrocarbon for 45 days.

\begin{tabular}{|c|c|c|c|c|c|c|}
\hline \multirow{2}{*}{$\begin{array}{l}\text { Initial conc. } \\
\mathrm{gm} \mathrm{l}^{-1}\end{array}$} & \multicolumn{2}{|c|}{ phenanthrene } & \multicolumn{2}{|c|}{ anthracene } & \multicolumn{2}{|c|}{ phenol } \\
\hline & $\%$ degradation & residue & $\%$ degradation & residue & $\%$ degradation & residue \\
\hline 1 & 99.9869 & 0.00013 & 99.9837 & 0.000162 & 96.035 & 0.03965 \\
\hline 2 & 99.4213 & 0.00578 & 99.4712 & 0.005288 & 99.485 & 0.00514 \\
\hline 3 & 99.9853 & 0.00014 & 99.9787 & 0.000212 & 99.757 & 0.00242 \\
\hline 4 & 99.7072 & 0.00292 & 99.7685 & 0.002315 & 99.818 & 0.00181 \\
\hline 5 & 99.8603 & 0.00139 & 99.8435 & 0.001565 & 99.128 & 0.00871 \\
\hline
\end{tabular}

ACATCTCCCTCAATCCTATTTTTTATAGAGAATGAGATCAGAGATAAATTATAAATGGTCCTGGGTAAGCTGTGCTATA
GTCTTTATTGACTATACCTGACGGAATTCTATCACTACCCGCCCTTATATCTTTATGGTATAAGCTCGGTGCTAGGAGGT
AGGAGCATAGTAAAGAACCTAACTTGCCTTTGTCAGCCTTCTTCATTGAAGGACATGATGCGACTGTGGGACGCCCGATT
ACCCTCGACTTAAATATCTGTTAAGGTTAAATTCTTGACTAATCCTTTTGCAAAAAAGAATTATGATAGAATTGGCTTTA
ATGTTTTACATCTAGAGTTATAAATCATTTTGACTCCTGATGGGAAAAAAAGCTCAAGAGTTCTTTACGAATTCTTTG
CCCACTTTTCCATTTTTTTGGCCTGAAATCAGATGGGACTACCCGCTGAACTTAAGCATATCAATAAGCGGAGGA

Fig. 4 18s ribosomal RNA gene among the selected strains (unknown).

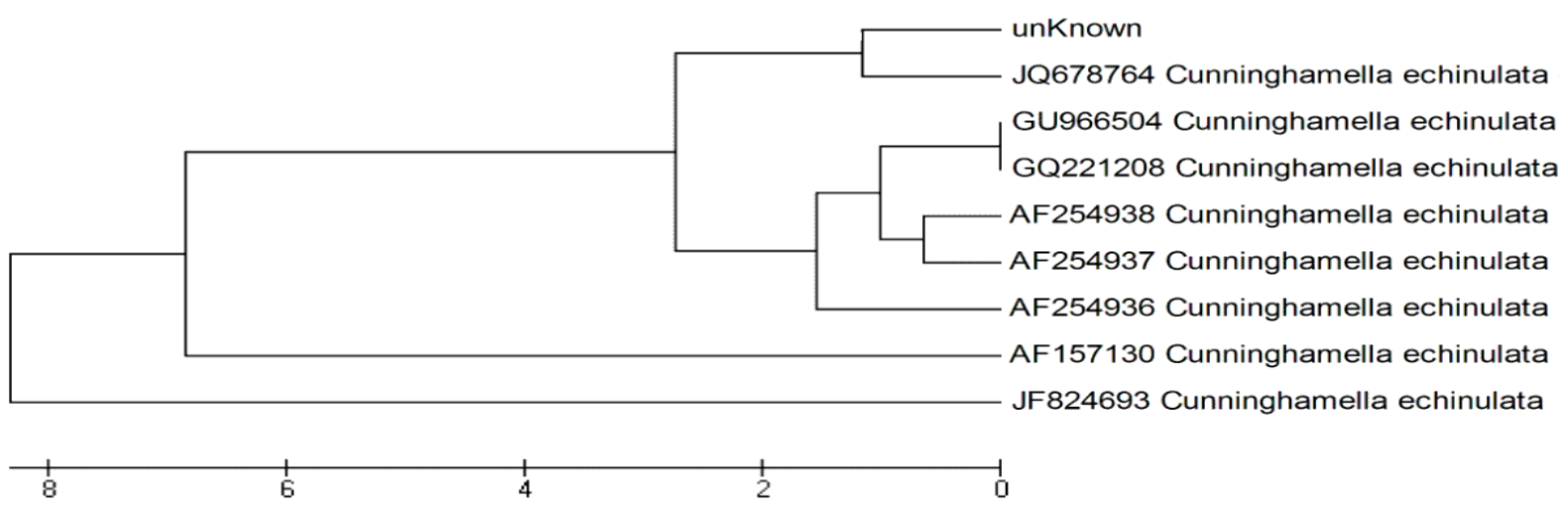

Fig. 5 Phylogenetic relationships among the selected strains (unknown) based on sequence analysis and the most closely related fungal species.

The specific laccase activities in cell free extract and culture media was determined (Fig. 6). Fig. 6 and Table 4 illustrates that the laccase activity was increased gradually until the end of the experiment (45 days of incubation period) with the highest activity values of 0.3133 , $0.6767,0.7800,1.5233$ and 1.5833 at $1,2,3,4$ and $5 \%$ of the mixture of PAHs. There was a significant difference between laccase activity (LSD at 0.05 Level). Therefore, the increased of laccase activity can be explained for the substance conversions and mineralization of the substrates. Similar results were observed by Waarde et al. [45] and Margesin and Schinner $[46,47]$. Also the previous authors noted that there is an increase of laccase activity and they explained this decrease of biological activities as the lack of growth factors, accumulation of inhibiting metabolites and of recalcitrant long- 
chain alkanes, high-branched aromatics and condensates [46].

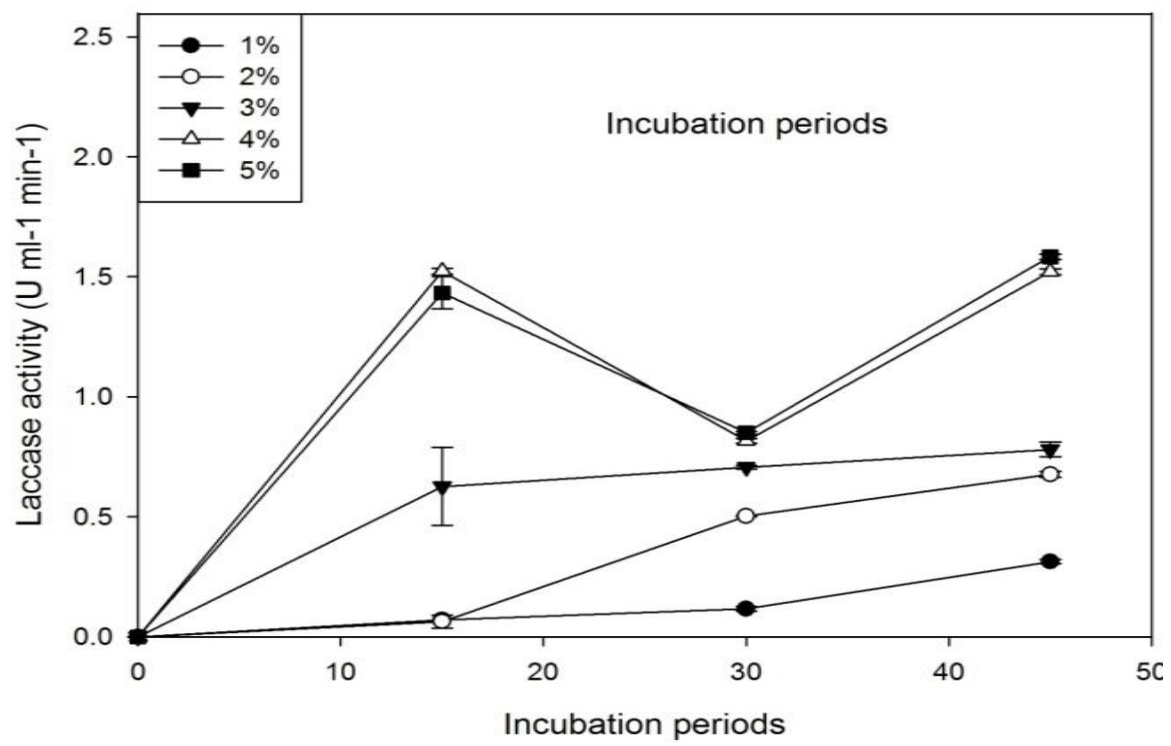

Fig. 6 laccase activity of Cunninghamella grown in $1 \%-5 \%$ of mixing polyhydrocarbon (PH, ANT AND PHE) for 45 days, Data are represented as means of three replicates with standard errors.

Table 4 laccase activity of Cunninghamella grown in $1 \%-5 \%$ of mixing polyhydrocarbon (PH, ANT AND PHE) for 45 days, Data are represented as means of three replicates with standard errors. Statistics was done using ANOVA (one way) at $\mathrm{p} \leq 0.05$,

\begin{tabular}{cllcll}
\hline Time & \multicolumn{5}{c}{ Conc. } \\
\cline { 2 - 6 } & \multicolumn{1}{c}{$\% 1$} & \multicolumn{5}{c}{$\% 3$} & \multicolumn{1}{c}{$\% 5$} \\
\hline 15 & $0.0700 \pm 0.00^{\mathrm{a}}$ & $0.0633 \pm 0.026^{\mathrm{a}}$ & $0.6267 \pm 0.16^{\mathrm{a}}$ & $1.5233 \pm 0.01^{\mathrm{a}}$ & $1.4333 \pm 0.06^{\mathrm{a}}$ \\
30 & $0.1167 \pm 8.82 \mathrm{e}-3^{\mathrm{b}}$ & $0.5033 \pm 3.33 \mathrm{e}-3^{\mathrm{b}}$ & $0.7067 \pm 6.67 \mathrm{e}-3^{\mathrm{b}}$ & $0.8167 \pm 8.82 \mathrm{e}-3^{\mathrm{b}}$ & $0.8500 \pm 5.78 \mathrm{e}-3^{\mathrm{a}}$ \\
45 & $0.3133 \pm 8.82 \mathrm{e}-3^{\mathrm{c}}$ & $0.6767 \pm 0.012^{\mathrm{c}}$ & $0.7800 \pm 0.03^{\mathrm{c}}$ & $1.5200 \pm 0.01^{\mathrm{c}}$ & $1.5833 \pm 0.01^{\mathrm{a}}$ \\
\hline
\end{tabular}

Different letters in the same column refers to significant difference

The efficiency of a certain catabolic pathway often depends on the properties of the involved key enzyme(s). Little is known about phenol metabolism in mycelial fungi. The specific laccase activities in cell free extract and culture media are shown in Fig. 6. This mechanism may contribute to metabolic adaptation of ubiquitous fungus found in nature, such as Graphium, Aspergillus and Penicillium, exposed to xenobiotic and aromatic compounds.

Finally, we can conclude that Cunninghamella echinulata showed a high ability for PAHs degradation and high activity of laccase. So, it is recommended to be use as a bioremediant of polluted areas.

\section{Acknowledgments}

The authors deeply thank Mansoura University, Damietta University and Department of Molecular Plant Pathology, Arid Lands Cultivation Research Institute (ALCRI) City for Scientific Researches and Technology
Application, New Borg EL-Arab, Alexandria, Egypt for supporting and funding this investigation.

\section{References}

[1] E.E. Hafez, M. Rashad, H.E. Abd-Elsalam, A.A. EL-Hanafy, The polyaromatic hydrocarbons as a serious environmental pollutants and the role of bioremediation to overcome this problem. (Environment, Healthy and Nutrition-Global Issues. S.K. Basu, S. Datta Banik eds) APH Publishing Corporation, New Delhi, India (2008) 445

[2] A.R. Johnsen, L.Y. Wick, L. Harms, Principle of microbial PAH-degradation in soil. Envi. Pollut. 133 (2005) 71

[3] Y. Kasai, K. Shind, S. Harayama, N. Misawa, Molecular characterization and substrate preference of a polycyclic aromatic hydrocarbons dioxygenase from Cycloclasticus sp. StrainA5. Applied Environ. Microbiol. 69 (2003) 6688

[4] J.B. Sutherland, A.L. Selby, J.P. Freeman, P.P. Fu, D.W. Miller, C.E. Cerniglia, Identification of 
xyloside conjugates formed from anthracene by Rhizoctonia solani. Mycol. Res. 96 (1992) 509

[5] K. Bandyopadhya, D. Das, B.R. Maiti, Kinetics of phenol degradation using Pseudomonas putida MTCC 1194. Bioprocess Eng. 373 (1999) 7

[6] M. Alexander, Biodegradation: Problems of molecular recalcitrance and microbial infallibility. Adv. Appl. Microb. 7 (1965) 35

[7] M.S. Ammar, E.A. Shady, Biotechnological bioremediation of oil spills for more clean Egyptian environments. Proceedings of the Third International Conference for Environmental Management and Technologies, 29-31 October, (2001) 738

[8] E.M El-Morsy, Evaluation of microfungi for the bioremediation of diesel oil in Egypt. Land Contamin.Reclam. 13 (2005) 147

[9] E. Rosenberg, The hydrocarbon-oxidizing bacteria. Ecophysiology, isolation, identification, application. The Prokaryotes: A handbook on the biology of bacteria (A. Balows, H. G. Trüper, M. Dworkin, W. Harder, K. Schelifer eds) Springer, New York (1991) 446.

[10] M. Alexander, Bioremediation technologies. Biodegradation and Bioremediation. Academic Press, London, New York (1994) 248

[11] T.K. Kirk, W.J. Connors, J.G. Zeikus, Requirement of growth substrate during lignin degradation by two wood rotting fungi. Appl. Environ. Microbiol. 32 (1976) 192

[12] R.T. Lamar, J.W. Evans, J. Glaser, Solid phase treatment of pentachlorophenol-contaminated soil using lignin degrading fungi. Environ. Sci. Technol. 27 (1993) 2566

[13] M.W. Davis, J.A. Glaser, J.W. Evans, R.T. Lamar, Field evaluation of lignin degrading fungus Phanerochaete sordida to treat creosote contaminated soil. Environment of Sci. Technology 27 (1993) 2572

[14] S.L. Wu, L.J. Mickley, D.J. Jacob, D. Rind, D.G. Streets, Effects of 2000-2050 changes in climate and emissions on global tropospheric ozone and the policy-relevant background surface ozone in the United States. Journal of Geophysical research 113 (2008) 18312

[15] M. L., Jackson. Soil chemical analysis. PrenticeHall of India Private Limited, New Delhi (1967) 498

[16] C.S.C. Piper, Soil and plant analysis. Inter. Pub. Inc. New York, (1947) 124

[17] S.E. Allen, H.M GrimShaw, A.P. Rowland, Chemical analysis. In: Methods in plant ecology (S.P.D. Moore, S.B. Champman eds), Blackwell, Oxford (1986) 285

[18] J. M. Bremner,. Determination of nitrogen in soil by Kjeldahl method. J. Agric. Sci. 55 (1960) 11

[19] M. Delory, Colorimetric estimation of ammonia. Vogel inorganic chemistry. Longman group Lid. London (1949) 145

[20] American Public Health Association, American
Water Works Association and Water Pollution Control Federation Standard Methods for the Examination of Water and Waste Water. American Public Health Association Office, 1015 Fifteenth st. NW Washington (1985) 20005

[21] M.K.C. John.Colorimetric determination of phosphorus in soil and plant materials with ascorbic acid. Soil Sci. 109 (1970) 214

[22] J.A Arx von, The Genera of Fungi Sporulating in Pure Culture. Lehre. J. Cramer. Germany 3 (1974) 124

[23] G.L. Barron, The Genera of Hyphomycetes from Soil. The Williams and Wilkins Company, Baltimore, USA 2 (1968) 1264

[24] K.H. Domsch, W. Gams, T.H. Anderson, 2 (1980) 405

[25] M.B. Ellis, Dematiaceous hyphomycetes. Commonwealth Mycological Inst. Kew, Surrey, England 125 (1971) 30

[26] M.B. Ellis, More Dematiaceous hyphomycetes. Commonwealth Mycological Inst. Kew, Surrey, England 3 (1976) 507

[27] Z.Z. Kozakiewic, Aspergillus species on stored products. Mycological Papers 1 (1989) 161

[28] K.B. Raper, D.I. Fennel, The genus Aspergillus. Williams and Wilkins Baltimore USA 25 (1965) 686

[29] K.B. Raper, C. Thom, A manual of Penicillia. Williams and Wilkins Baltimore USA 111 (1949) 40

[30] M.A. Rifai, A revision of the genus Trichoderma. Mycological paper, Commonwealth Mycological Inst. Kew, Surrey, England 1 (1969) 56

[31] T.J. White, T. Bruns, S. Lee, J. Taylor, Amplification and direct sequencing of fungal ribosomal RNA genes for phylogenetics. In: PCR Protocols: a guide to methods and applications. (M.A. Innis, D.H. Gelfand, J.J. Sninsky, T.J. White eds). Academic Press, New York, USA (1990) 315

[32) S.F. Altschul, T.L. Madden, A. Schaffer, J. Zhang, Z. Zhang, W Miller., D.J. Lipman, Gapped BLAST and PSI-BLAST: a new generation of protein database search programs. Nucleic Acids Research, 25 (1997) 3389

[33] J.D. Thompson, D.G. Higgins,. T.J. Gibson, Clustal W: improving the sensitivity of progressive multiple sequence alignment through sequence weighting, position-specific gap penalties and weight matrix choice. Nucleic Acids Res. 22 (1994) 4673

[34] K. Tamura, J. Dudley, M. Nei, S. Kumar, MEGA4: Molecular Evolutionary Genetics Analysis (MEGA) software version 4.0. Molecular Biology and Evolution 24 (2007) 1596

[35] B.E. Anderson, T. Henrysson, Accumulation and degradation of dead -end metabolites during 
treatment of soil contamined with polycyclic aromatic hydrocarbons with five strains of whiterot fungi. Appl. Microbiol. Biotechnol. 46 (1996) 647

[36] D.W. Gao, Y.G. Zeng, X.H. Wen, Y. Qian, Competition strategies for the incubation of white rot fungi under non-sterile conditions. Process Biochem. 43 (2008).937

[37] R.C. Prince, Petroleum and other hydrocarbons biodegradation. (G. Bitton ed) Encyclopedia of Environmental Microbiology. John Wiley, New York (2002) 2402

[38] J.S. Heath, K. Kobis, S.L. Sayer, Review of chemical, physical and toxicological properties of components of total petroleum hydrocarbons. J. Soil Contamination 2 (1993) 221

[39] T.J. White, T. Bruns, S. Lee, J. Taylor, Amplification and direct sequencing of fungal ribosomal RNA genes for phylogenetics. In: PCR Protocols: a guide to methods and applications. (M.A. Innis, D.H. Gelfand, J.J. Sninsky, T.J. White eds). Academic Press, New York, USA (1990) 315

[40) S.F. Altschul, T.L. Madden, A. Schaffer, J. Zhang, Z. Zhang, W Miller., D.J. Lipman, Gapped BLAST and PSI-BLAST: a new generation of protein database search programs. Nucleic Acids Research 25 (1997) 3389

[41] J.D. Thompson, D.G. Higgins,. T.J. Gibson, Clustal W: improving the sensitivity of progressive multiple sequence alignment through sequence weighting, position-specific gap penalties and weight matrix choice. Nucleic Acids Res. 22 (1994) 4673

[42] B.J. Reid, K.C. Jones, K.T. Semple, Bioavailability of persistent organic pollutants in soils and sediments--a perspective on mechanisms, consequences and assessment. Environ Pollut. 108 (2000) 103

[43] F. Schinner, R. Öhlinger, E. Kandeler, R. Margesin, Methods in Soil Biology. SpringerVerlag (1996) 206

[44] R. Margesin, G. Walder, F. Schinner, The impact of hydrcarbon remediation (diesel oil and polcyclic aromatic hydrocarbons) on enzyme activities and microbial properties of soil assessment. Environ. Pollut. 108 (2000) 103

[45] J.J. Waarde, E.J. van der Dijkhuis, M.J.C. Henssen, S Keuning, Enzyme assays as indicators for biodegradation (W.J. In van den Brinck, R. Bosman, F. Arendt eds). Contaminated Soil'95. Kluwer Academic Publishers. Dordrecht Kluwer, London, New York (1995) 1377

[46] R. Margesin, F. Schinner, A feasibility study for the in situ remediation of a former tank farm. World J. Microbiol. Biotechnol. 15 (1999) 615

[47] R. Margesin, F. Schinner, Bioremediation (Natural attenuation and biostimulation) of diesel-oil-contaminated soil in an Alpine Glacier Skiing area. Applied and Environmental Microbiology 67 (2001) 3127

\section{المعالجة البيولوجية لمركبات الانثراسين والفينانثرين والفينول بفطرة كانينجهاميلا اكانيولاتا}

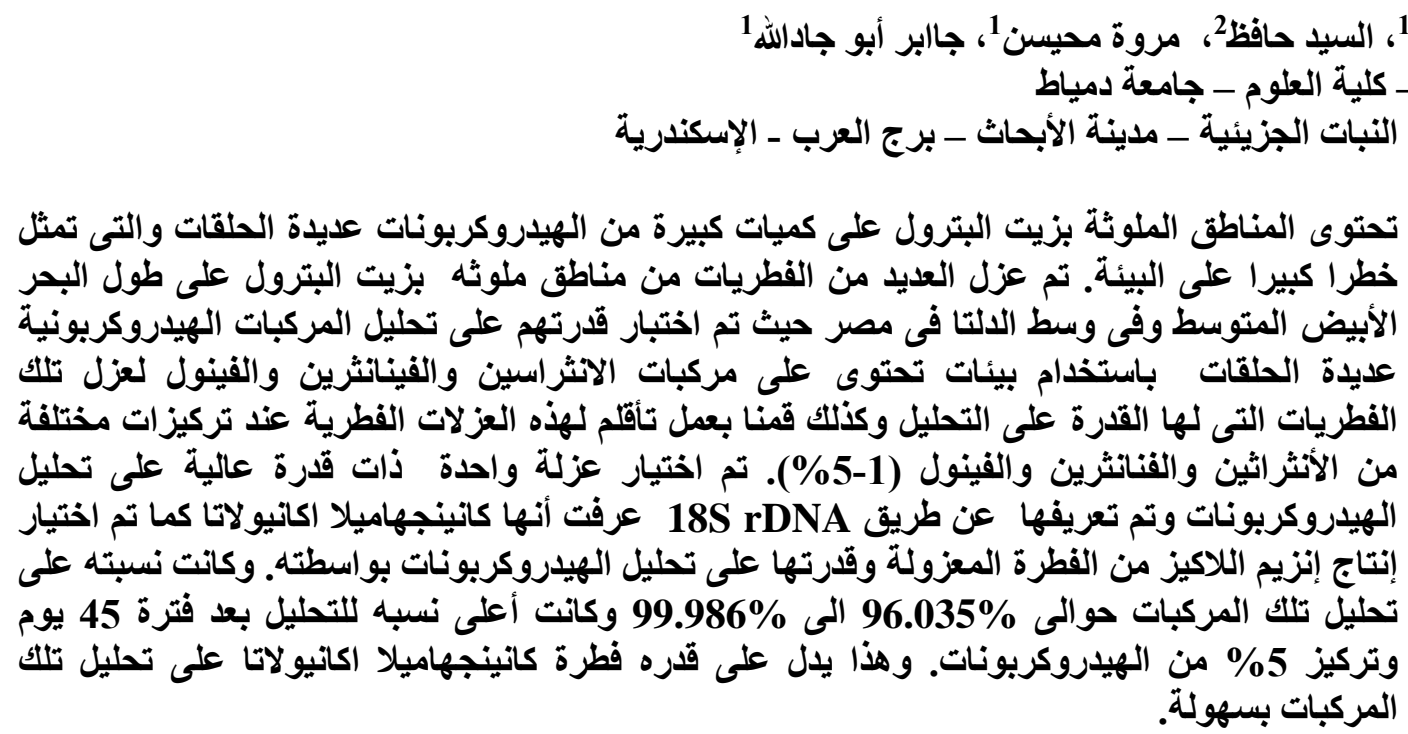

